\title{
A NEW SPECIES OF SCANIA OLIVARES (LEPIDOPTERA, NOCTUIDAE, AUSTRANDESIINI)
}

\section{UNA NUEVA ESPECIE DE SCANIA OLIVARES (LEPIDOPTERA, NOCTUIDAE, AUSTRANDESIINI)}

\author{
Tania S. Olivares ${ }^{1} \&$ Andrés O. Angulo ${ }^{2}$ \\ ${ }^{1}$ Casilla 4040 Correo 3. Concepción. Chile. E-mail: tolivare@udec.cl \\ ${ }^{2}$ Universidad de Concepción. Facultad de Ciencias Naturales y Oceanográficas. Departamento de Zoología. Casilla \\ 160-C. Concepción. Chile. E-mail: aangulo@udec.cl
}

\begin{abstract}
This work presents a new species closed to S. strigigrapha (Hampson), S. trimaculata sp.nov., from the high Andean region (Las Trancas, VIII Region, Chile). The adult male and its genitalia are described and illustrated.

Keywords: Taxonomy, S. trimaculata n. sp., S. strigigrapha Hampson, High Andean region, Chile.

\section{RESUMEN}

Se describe una nueva especie próxima a $S$. strigigrapha (Hampson) nominada $S$. trimaculata n. sp. de la región altoandina (Las Trancas, VIII Región, Chile). Se describen e ilustran el adulto y su genitalia.

Palabras claves: Taxonomía, S. trimaculata n. sp., S. strigigrapha Hampson, región altoandina, Chile.
\end{abstract}

\section{INTRODUCTION}

The genus Scania Olivares was described in Olivares (1994) and consists of 10 species, and was described fully in that work. A character, ampulla aviformis, was used in the genus definition, but the presence, in some species as well as in this new species, of a small digit that permits a more successful mating. This work describes the adult and male genitalia of this new species.

\section{MATERIALS AND METHODS}

The material reviewed in this present work comes from the Museum of Zoology of the Universidad de Concepción (UCCC), where the types are deposited. The descriptions are made on the based on the wing maculation and the male genitalia structure sensu Angulo \& Weigert (1977). The scales in photographs corresponding to $0.5 \mathrm{~cm}$.

Scania trimaculata sp. nov.

DESCRIPTION:

Holotype male (Fig. 11): head, palpus, chocolatebrown patagia and tegulae, bipectinate antennae on thorax, forewings with scales of chocolate-brown background, mixed with some black scales, costal border of the wing with chocolate-brown mixed with black scales, that form the beginning of bands but that do not continue; orbicular, reniform and claviform spots with brown-yellowish scales 
delimited by chocolate-brown scales, fore legs with brown scales, middle and hindlegs with dark-brown scales. Hind wings white with dark brown scales in the veins and the coastal border of the wing.

Genitalia (Figs. 12-13): Valves rounded without the presence of a neck opening or a hadenid-neck, very weak crown, clasper in bird form, unique this genus, crenulated in its superior and internal lateral portion, protruding from the valve, presents an almost imperceptibly small digit, a simple uncus with four spines, saccus acute, juxta with a spiniform process in its basal portion, aedeagus with three simple spines and a bulbous base.

Female: Unknown

Material eXAmined: 1 holotype male, Las Trancas, Chillán, 17-I-53, L. E. Peña coll. (gen. prep.) (UCCC)

Wing expansion: $24 \mathrm{~mm}(\mathrm{n}=1)$

Observations: This species has male genitalia similar to the species $S$. strigigrapha (Hampson) in its form of the clasper and in the number of spines in the aedeagus, but differs in the juxta because $S$. trimaculata n. sp., presents a spine at the base of the juxta (Figs. 14-15). The size and ground colours differs from other species as is shown in Figs. 1 to 10 .

Eтүмоlogy: tri: three; maculata: mark, referring to the three brown-yellowish spots that are present in the forewings.

\section{DISCUSSION AND CONCLUSIONS}

The species that share the plesiomorphic characteristic (sensu Olivares 1994) of the presence of the digit are Scania neuquensis (Koehler), S. perornata (Koehler), S. strigigrapha (Hampson), S. odontoclasper Olivares. The rest of the species do not present the digit.

The distribution that was found for the new species, Las Trancas, Chillán, Chile (29 $\left.24^{\circ} \mathrm{S}, 70^{\circ} 18^{\prime} \mathrm{W}\right)$ widens the range of the species, which is found in the Western Branch of the Southern Andean Mountains that lies between Concepción, Chile ( $\left.36^{\circ} 50^{\prime} \mathrm{S}, 73^{\circ} 03^{\prime} \mathrm{W}\right)$ and the Bandurrias River, Chile $\left(50^{\circ} 44^{\prime} \mathrm{S}, 72^{\circ} 25^{\prime} \mathrm{W}\right)$ (Olivares 1994) where S. trimaculata n. sp. it is the most septentrional species of its genus.

\section{ACKNOWLEDGMENTS}

This research was financed by the Universidad de Concepción, Research Project No. 203.113.060-1.0. We would also like to thank Ms. Marcela A. Rodríguez for her illustration assistance.

\section{BIBLIOGRAPHY}

Angulo, A.O. \& GTH. Weigert. 1977. Pseudaletia punctulata (Blanchard) y Pseudaletia impuncta (Guenée): nóctuidos hadeninos similares en Chile. (Lepidoptera: Noctuidae). AgroSur 5(1): 12-17.

Olivares, T. S. 1994. Sistemática y filogenia de las especies del género Scania n. gen. (Pseudoleucania in part) (Lepidoptera: Noctuidae) de la subregión andinopatagónica. Gayana Zool. 58 (1): 27-60. 

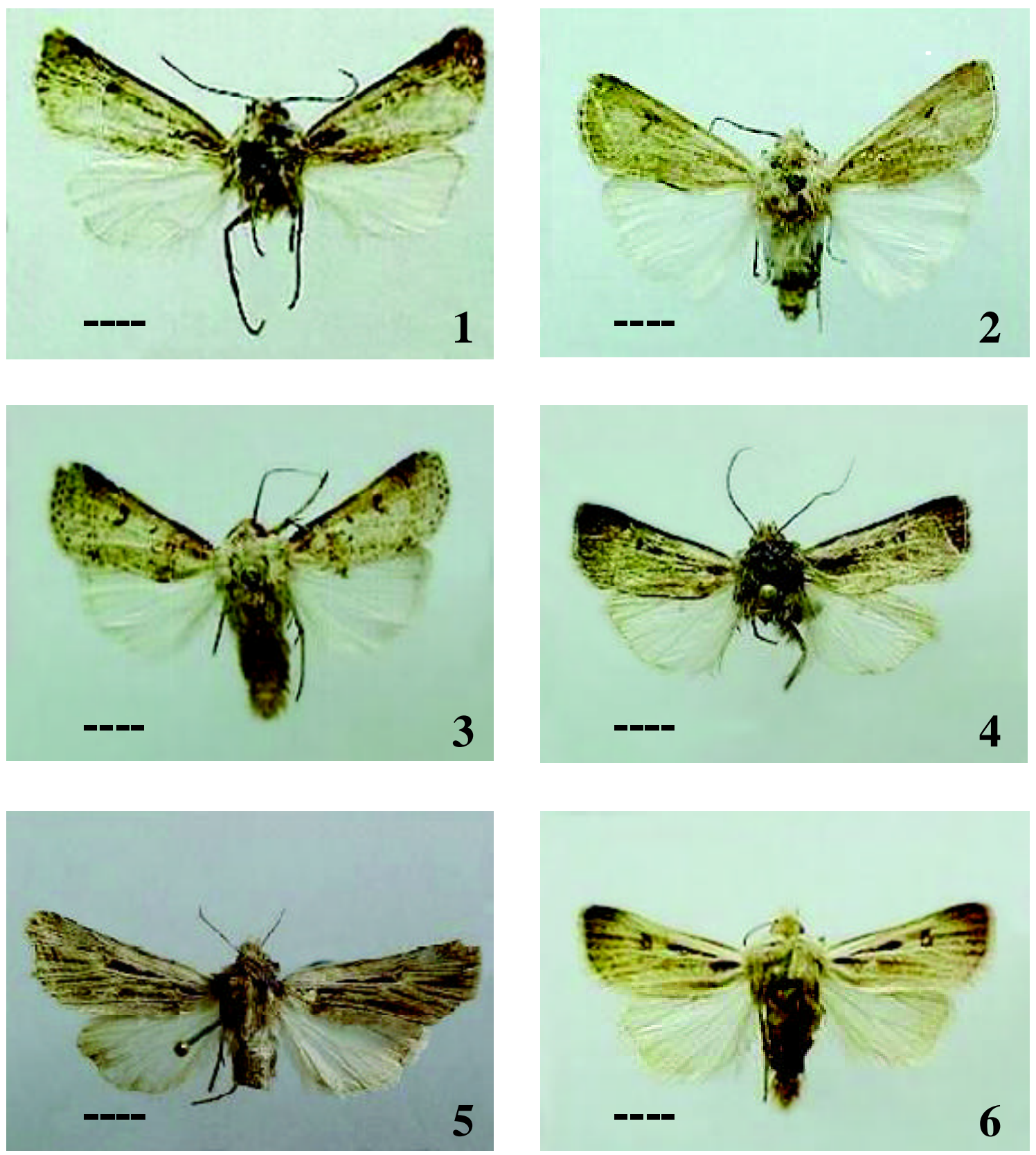

Figures 1-6: Fig. 1. S. anelluspinata Olivares, Fig. 2. S. aspersa (Guenée), Fig. 3. S. messia (Butler), Fig. 4. S. neuquensis (Koehler), Fig. 5. S. odontoclasper Olivares, Fig. 6. S. perlucida (Koehler).

Figuras 1-6: Fig. 1. S. anelluspinata Olivares, Fig. 2. S. aspersa (Guenée), Fig. 3. S. messia (Butler), Fig. 4. S. neuquensis (Koehler), Fig. 5. S. odontoclasper Olivares, Fig. 6. S. perlucida (Koehler). 

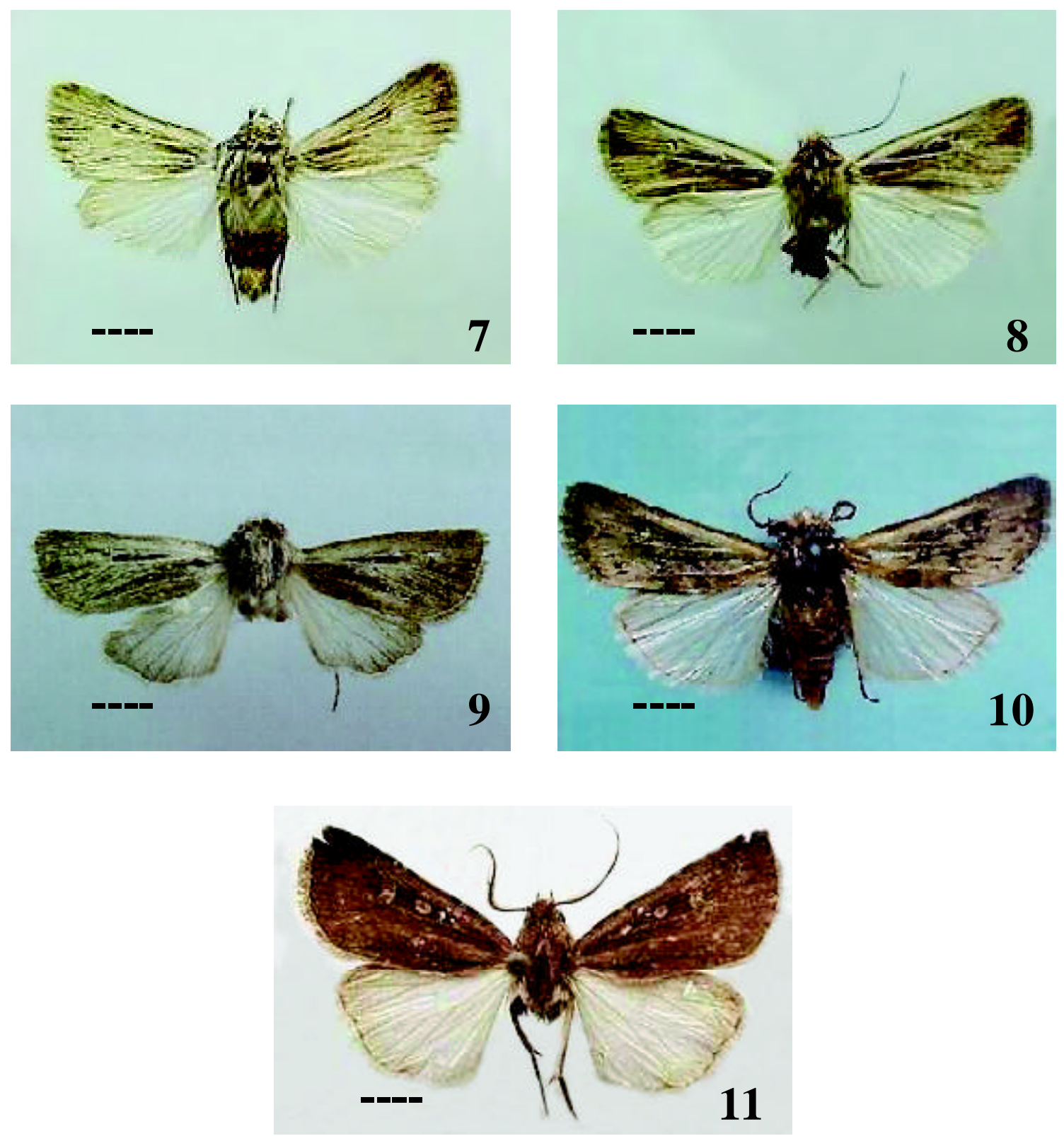

FIgUREs 7-11: Fig. 7. S. perornata (Koehler), Fig. 8. S. simillima (Koehler), Fig. 9. S. strigigrapha Hampson, Fig. 10. S. tephra (Koehler), Fig. 11. S. trimaculata n. sp.

Figuras 7-11: Fig. 7. S. perornata (Koehler), Fig. 8. S. simillima (Koehler), Fig. 9. S. strigigrapha Hampson, Fig. 10. S. tephra (Koehler), Fig. 11. S. trimaculata n. sp. 
A new species of Scania Olivares: Olivares, T. S. \& A.O. Angulo

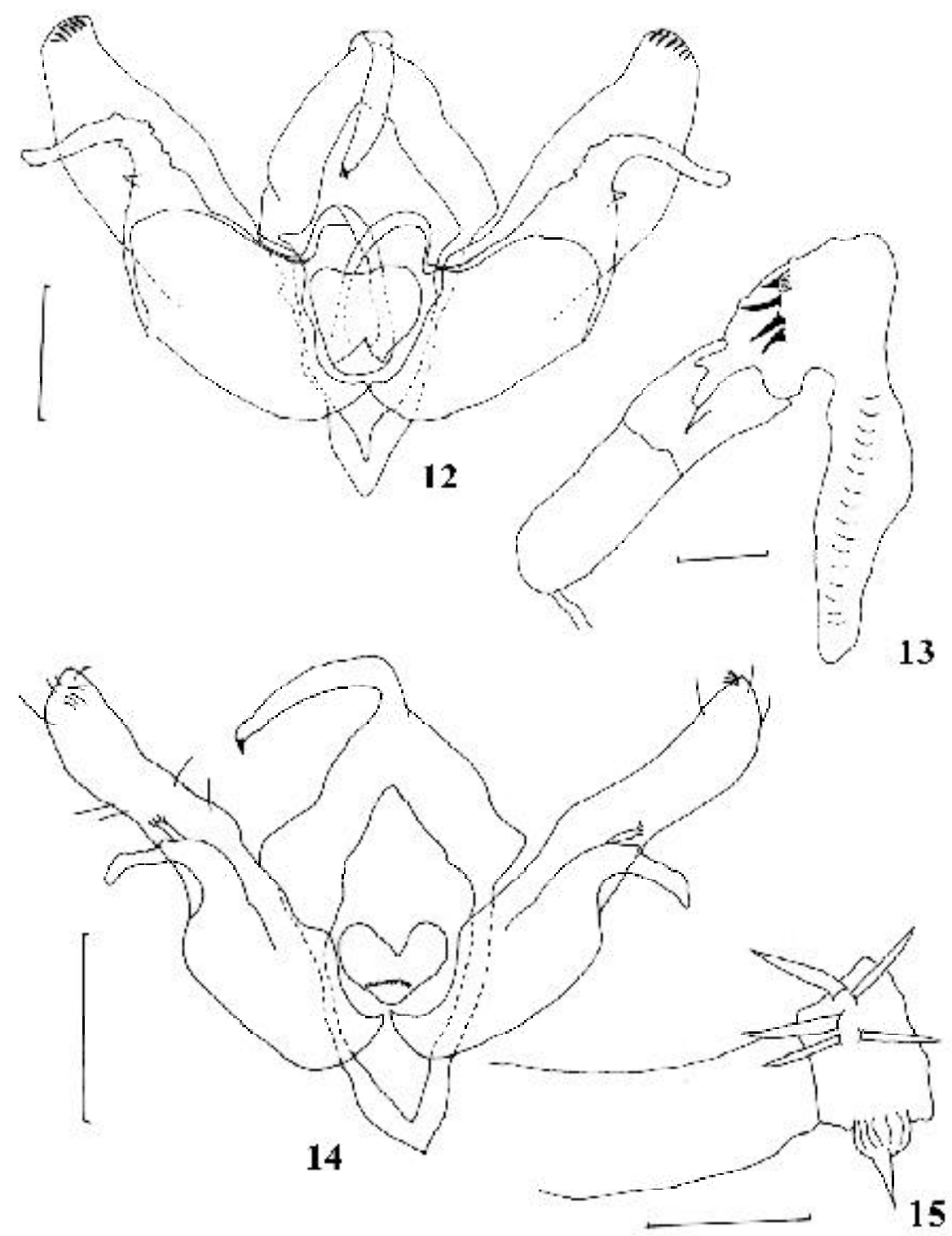

Figures. 12-13. Male genitalia ventral view and aedeagus S. trimaculata; Figs. 14-15. Male genitalia ventral view and aedeagus S. strigigrapha.

Figuras. 12-13. Vista ventral de la genitalia del macho y aedeagus S. trimaculata; Figs. 14-15. Vista ventral de la genitalia del macho y aedeagus $S$. strigigrapha.

Fecha de recepción: 20/10/03

Fecha de aceptación: 10/03/04 